Gramáticas de la (¿post?) violencia:

identidades, guerras, cuerpos y fronteras

\title{
Land as Home: Women, Life and Violence in Land Conflicts
}

\author{
Dibe Ayoub' \\ ' Universidade Federal do Rio de Janeiro, Museu Nacional, \\ Programa de Pós-Graduação em Antropologia Social, Rio de Janeiro/RJ, Brasil
}

\begin{abstract}
This work analyses how women question experiences of violence in land conflicts in Pinhão, Paraná, Southern Brazil. Land conflicts strike at the very foundation of the livelihood of families and communities, having a direct bearing on houses, which are places that objectify the occupation of the land and where ties of belonging between subjects and territories are woven. Land is home; land and violence are therefore also constituted as problems for women and as matters that encompass gender relations. In women's narratives, violence is appraised through ethical ways of family and community living, and emerges in the following concrete acts: killings, house fires, threats, ambushes, and evictions. These acts intrude on the enduring conviviality of everyday life and the relations that compose communities.
\end{abstract}

Keywords: violence; conflict; land; ethics; gender. 


\section{A terra como lar: mulheres, vida e violência em conflitos por terra}

\section{Resumo}

Neste trabalho, busco compreender como mulheres problematizam experiências de violência vividas em conflitos por terra em Pinhão, Paraná, sul do Brasil. Conflitos por terra avançam sobre os solos de existência de famílias e comunidades inteiras, afetando diretamente as casas, lugares que dão materialidade à ocupação da terra e onde laços de pertencimento entre pessoas e territórios são construídos. A terra é lar, de modo que a violência nesses conflitos é também enfrentada por mulheres e envolve relações de gênero. Nas histórias delas, a violência é considerada a partir da ética da vida em família e comunidade e emerge como atos concretos: mortes, incêndios contra casas, ameaças, emboscadas, despejos. Tais atos adentram o convívio entre pessoas, permanecendo no cotidiano e nas relações que constituem comunidades rurais.

Palavras-chave: violência, conflito, terra, ética, gênero. 


\title{
Land as Home: Women, Life and Violence in Land Conflicts
}

\author{
Dibe Ayoub
}

Land conflicts are infused with violence that affects all of the family members that live in a disputed area. Land is not just an object that is owned. It is a living body that connects to all the features of social life, such as kinship, residence, work, community, environment, history and so forth. Processes of expropriation can thus tear up relations and forms of living that make up the grounds of people's existence. Whenever land is the object of hostility, violence is directed against family homes; when we consider violence in these terms, it also becomes clear that it has a major impact on the lives of women. ${ }^{1}$

In this article, I address how women from the municipality of Pinhão understand and question violent acts that occur in the context of land conflicts. In the stories they told me, violence is discussed from within the meshwork of the community and it emerges as specific acts carried out by familiar persons. Moreover, women are not simply potential victims of killings. They can also kill and take part in "vengeances". Gender relations and the ethical construction of women in rural communities are thus a central theme in plots that convey how violence is experienced in quotidian contexts, whenever the place a family inhabits becomes a disputed entity.

As the stories of Dona Francisca and Dona Ana that I will analyse below attest, women play an important role in the production of their family's land. Even though men in Pinhão are considered to be the agents who "must work", who are usually publically recognized as the "owners" of the land, and who are therefore most accountable for it, women are also committed to the protection of their family's territories and lives. When we bring their experiences to the foreground, violence during land conflicts emerge as a series of acts that encompass the house and social intimacy. Power relations, expropriation and political struggles are also entailed in practices of relatedness that weave forms of acquaintance, belonging and coexistence in Pinhão.

A number of scholars have investigated land and territorial conflicts in Brazil, focusing particularly on colonization and forms of territorial and economic domain which shape the country's high levels of social inequity. There is a recurring observation in the work of the authors who have addressed the problem of violence in land conflicts in Brazil: that the spread of Capitalism and technology has failed to consolidate democratic practices or further social equality (Martins 1981; Barreira 1992; Medeiros 1996; Brumer \& Tavares dos Santos 2006). On the contrary, what we find is systemic and authoritarian violence against rural workers (Velho 1976), tied to modes of domination that connect private interests to the workings of the State. Violence is therefore the brutal facet of ongoing processes, the main objectives of which are to expel people from the territories they inhabit, or to force them to live under the rules of companies and powerful landowners.

While I agree with these considerations regarding land conflicts, I differ in focusing on how women live through acts of violence within a particular conflict, acts that consist mainly of killings, persecutions, ambushes, fire, shootings. Pinhão's dwellers have taught me that in order to understand the unfolding of such acts, I had to appreciate other aspects of their agonistic relationships. Killings are experienced in ethical ways wherein community and kinship relations are matters for and through action, bonds that are

\footnotetext{
1 I would like to thank Adriana Villalón and Natalia Cabanillas encouraging this article. I also thank the outstanding contributions of the anonymous reviewers.
} 
continually constructed through social practice. As Foucault (1984) suggests, "ethics" comprises processes of "problematization", attention, thought and care for one and for others. In Pinhão, the act of killing is questioned and measured in terms of what is intelligible or abhorrent, typical or absurd. "Vengeance", for instance, is conceived as a common way "to resolve" a specific death and it is hence the means through which a killing pervades and unsettles daily routine. Homicides over land conflicts can therefore also engender "vengeances" that have an enduring impact on people's lives. In contrast, random shootings at houses, arson and the murder of children are interpreted as absurd practices that exceed quotidian expectations. Yet those who perform such atrocities live very close to their victims, introjecting fear and treason into people's coexistence in rural communities. Violent acts as part of land conflicts are hence interwoven into the forms of living that constitute the rural communities of Pinhão and permeate women's lives.

Pinhão is a municipality in the state of Paraná, located in Southern Brazil. Situated in a landscape of araucaria pine forests, Pinhão was traditionally coveted by lumber companies, among which João José Zattar Industries was the most prominent. Zattar, as the residents of Pinhão call the company, arrived in Pinhão at the end of 1940's, built a sawmill and, later, a gated settlement named Zattarlândia. Between 1960 and 1970 the company acquired the titles to lands beyond Zattarlândia. Numerous families, who did not have land titles, lived in these areas according to the faxinal system, a traditional form of territorial occupation in the region which involves common land use $\mathrm{e}^{2}$.

The company placed armed men in the lands it acquired, so as to secure the company's territorial domain. The dwellers of Pinhão called these men "guards", jagunços ("bandits", "outlaws") and "hit men". They resided within the areas that Zattar had titled, deterring the dwellers from cutting wood, extracting yerba mate, and gathering pinhão (the seed of the araucaria pine, which is edible and much appreciated in southern Brazil). Dwellers were also forced to pay thirty percent of each family's harvest to the jagunços in retribution for living in the company lands. Many jagunços were involved in killings, threats, fire, and ambushes against the families who lived in areas acquired by Zattar. In women's narratives, the armed men are depicted as people who live close by, and whose families are known and sometimes related to the narrator. In this conflict, violence assumes a personal, familiar and ordinary character.

The company declared bankruptcy in 1994, but ownership of the lands remains uncertain. Deaths and hostilities that occurred during the conflict have become part of the relations that constitute the inhabitants of these territories. In 2006, Zattar signed an agreement with the National Institute of Colonization and Agrarian Reform (Incra), thereby starting the negotiation of some twenty one thousand hectares of land. Twelve years later, the deal has yet to be concluded. At present, there are various social movements based in those areas: the Squatters Movement (MP, Movimento de Posseiros), the Landless Rural Workers Movement (MST, Movimento dos Trabalhadores Rurais Sem Terra), the Small Farmers Movement (MPA, Movimento dos Pequenos Agricultores), and the Faxinalenses Peoples Puxirão Articulation (APF, Articulação Puxirão dos Povos Faxinalenses). ${ }^{3}$ In addition, there are other residents, such as the Junqueira

\footnotetext{
2 Faxinal, as the dwellers of Pinhão call it, is the name given to "bush" areas in forests of araucaria pine (Araucaria angustifolia). Such areas are traditionally used for free range livestock breeding and extraction of yerba mate (Ilex paraguariensis), which is carried out by a family in its own land. Until the arrival of the lumber industry and of other actors practicing private forms of land occupation, livestock was raised in common lands, called criadouros. Subsistence farming occurred in "crop lands", which were located in hillsides and river banks, far from the faxinais. Chang (1988), Porto (2013), Almeida (2006) and Souza (2010) discuss the combination of collective and private uses of land in Paraná's faxinais. In regards to the faxinais of Pinhão, Porto (2013) argues that, despite the fact that many communities do not have the collective criadouros anymore, their traditional ways of existence are present in their relations with the environment and their forms of conceiving the world.

3 While MST and MPA are national movements, the APF represents the traditional peoples of Paraná state. The Squatters Movement, in turn, was instituted in Pinhão in 1992, when the inhabittants of the lands acquired by Zattar joined forces to demand their land rights. They called themselves "squatters" due to their condition as people who live and work in the lands under dispute, but who do not own property titles in them.
} 
family, who claim these lands for themselves, and attack the members of social movements. Furthermore, the lumber company continues to be a threatening and destructive agent, which now acts through law suits seeking repossession that often result in the forced eviction of the inhabitants without land titles.

I have been carrying out fieldwork with families who live in the areas appropriated by the lumber industry since 2009. I stay in the homes of dwellers that are involved in different social movements and inhabit different communities. As a woman living inside family homes, I spend most of my time in the company of other women, and my conversations with men usually occur in the presence of their wives, mothers, daughters and children. Therefore, my emphasis on women's stories and on a perspective that interprets the conflicts from within the house is conditioned by the experiences that are available to me in the field. 4

In this article I discuss how violence is assessed and enacted in tandem with relationships that compose families and communities. I agree with Veena Das (2007) when she states that an analysis of violence should not be limited to events that are witnessed by the researcher, who must look at how violence affects social coexistence and poisons relationships. My interest lies in understanding how violence acts on and constitutes women, how it endures in everyday life and how it is incorporated into social relations that are conceived in ethical terms. In the first part of this article, I rely on Dona Francisca's story to discuss the distinctiveness of land conflicts as struggles that involve the violation of the house. The second part of the article is dedicated to the story of Dona Ana, who killed a jagunço and became an example of strength among local women involved in land conflicts. I then analyse the "oath of vengeance" that befalls Ana when the jagunço's daughters swear retaliation. "Vengeance" thus emerges as an issue for women and as a relation that is widely discussed in the community, hence becoming everyone's problem. Yet while killing and "vengeances" are accepted as possible acts within the agonistic dynamics of relationships, there are those acts that breach regular routine, emerging as excessive and transgressing conventional boundaries. The final part of this article is dedicated to the production of horror inside the community.

\section{Violence, land and women}

Dona Francisca is one of the squatter women that host me at their homes in the Pinhão countryside. The first time I met her she told me about the murder of her husband Leonardo and her experiences during the land conflict with Zattar. Her stories struck me for the strength she displayed in her confrontations with the company's armed men and managers after Leonardo's death, which left her a widow with three children to raise. Leonardo was one of Zattar's armed men. After his death, Francisca became a woman on a land that was not hers. She remained on the land and joined the Squatters Movement, through which she demands rights over the land she inhabits. I have been to Francisca's house and I have listened to her stories on the land conflicts a great many times. In the following pages, I intend to relay some of the ways through which she constitutes herself as the legitimate owner of her land. To this end, I discuss the mutual implications of land, gender and violence in land conflicts.

In 1970 Dona Francisca married Leonardo, who worked in the Zattar Industries sawmills. He was later given a new job offer from the company: they asked him to become a "guard", which is how Francisca refers to her husband's occupation. "Guards", jagunços and "hit men” are the terms used by Pinhão's dwellers for the armed men of Zattar Industries. By using these nouns, people express their judgments about the activities of these employees of the company (Ayoub 2013, 2015). "Guard" thus emerges as a moderate and respectful term, which highlights surveillance activities without conveying that the use of violence was part

4 This work was supported by the Projeto Memórias dos Povos do Campo no Paraná (ITCG/MinC) and AFATRUP (Pinhão's Rural Workers Association). I also received research grants from PPGAS/MN/UFRJ and Capes, and scholarships from Capes, Faperj and CNPq. 
of the job. Jagunço is a noun employed mostly by those intimately involved in conflicts with the company and who identify as members of social movements. It is a term that expressed the illegal use of force in safeguarding Zattar's territorial claims. Finally, "hit man" is a category that puts violence squarely at the forefront, designating a man who is paid to kill people.

Francisca has always called Leonardo a "guard", while she uses the term "hit men" to refer to his work colleagues. She stresses that he took the job "for the salary", not "to harm" someone. As well as the money, there was another material benefit that attracted him to work as a "guard": a house to live in and land to cultivate. Thus, in the late 1980s, Dona Francisca and Leonardo moved to the same area in which she she still lives, but which she does not hold titles to.

Leonardo worked as a "guard" until his death in the early 199os. He was killed on a Sunday, while watching a horse race in Zattarlândia. A man named Odair, who had recently moved in to the company's private settlement, shot Leonardo during the event. Odair then left Pinhão.

Francisca has often told me that she believes Leonardo's killing was arranged by his work colleagues, since he might have known something that they did not want disclosed, or perhaps because he had refused to take part in illicit activities. In her account, Odair is the thread that connects Zattar to the death of Leonardo. Although she never met him, she heard that he had killed people before. Whenever she speaks of Leonardo's work, she insists he was a good person, who only performed surveillance activities, and who had never killed anyone. He was a "guard", not a "hit man".

A month after Leonardo's death, Francisca went to the company's office in Zattarlândia to demand her husband's financial settlement, i.e., his Christmas bonus and holiday benefit. The company's manager laughed at her and said that they would not pay her a single cent. This humiliation devastated Francisca. But the event also created a debt: "you will still pay me", she thought to herself there and then. Recently, when we were talking about other squatters' problems with Zattar, she discussed her own ties to her land: "I stood here because they did not pay me what they owed my husband", she said. Francisca also claims that she was the one who "worked" in the land, breeding pigs and planting crops. Leonardo had not learned to perform these activities, for he always worked in sawmills, and when he became a "guard" his "work" again took him outside of the family's land.

Francisca recalls that a few weeks before he was murdered, Leonardo told her he could die because of his work. "If I die, you will not take our children and leave this land. You will stay right here", he told her, and then made her promise that she would not move away. Francisca therefore stood her ground. She had no money and nowhere else to go. Her younger brother moved in with her, to help her raise the children. They both began working in other people's lands because the company's armed men would not let them plant or extract yerba mate.

Five years after Leonardo's death, jagunços tried to remove Francisca from her land. One night, they shot against her rooftop, aiming to scare her into leaving. The company later sent the "hit man" Lauro to live in a house next to Francisca's fence. He and other armed men used to walk into her land to watch and frighten her family. They used her place as a path through which they moved freely, making it clear that it was not her property. Many times she extracted yerba mate and Zattar's men took the product from her. In those days, Amalia, a neighbour and friend, used to sleep over at Francisca's. She went whenever her husband was working away from home, for she feared that jagunços would come at night and burn her residence.

The experiences of Francisca and Amalia are typical of the forms of violence perpetrated in land conflicts. These disruptive processes sharply and systematically violate the space of the house. People can furthermore get murdered in their own homes, or have their houses burnt down. This violence is meant to put an end to the tenure that is assured by the presence of an inhabited house. 
If the house is a dynamic body, an extension of those who inhabit it (Carsten \& Hugh-Jones 1995), it also participates in a "configuration of houses" (Marcelin 1999). Through the making of kinship by relations of coresidence, the house ties itself to other houses. The destruction of a house does not only uproot the lives of its inhabitants, it also lacerates the meshwork of kinship and coexistence that constitute countryside communities. Additionally, the house is the place of a "family", where a couple and their children reside, but which also sometimes includes mothers and fathers-in-law, uncles and aunts, nieces and nephews, grandparents and their grandchildren.

The correspondences of gender and the organization of land have been a major focus in the works of Beatriz Heredia (1979), Klaas Woortmann (1990) and Ellen Woortmann and Klaas Woortmann (1997). These anthropologists, who carried out research in different parts of Brazil, emphasise the associations between, on the one hand, food-producing areas, the market and paternal relations; and, on the other, the house, nurture and the maternal relation. We find similar associations in Pinhão. "Work", understood as incomegenerating activity, is mostly considered to be a man's "duty". Yet women can also take part in "work" activities in and outside the family land, as Francisca always has. There are also female "services" which are ideally attached to household tasks, such as cleaning and cutting firewood. Women are also responsible for the kitchen, where they cook meals for their families and guests, thereby producing bodies and social bonds (Cerqueira 2017).

Nurturing and caring for children is also one of their central activities. Alongside house "services" and food preparation, motherhood is an important aspect of women's reputations in the Pinhão countryside. These traits are widely observed and discussed by the inhabitants of rural communities, which indicates that what a woman does inside her house is a topic of public conversation. Recent works on rural peoples in Brazil highlight the central role of mothers in the consolidation of family territories. The mother emerges in these works as the person that stabilizes the family in the land (Perutti 2015), or as the most stable tie in a world characterized by instability (Guedes 2013). As Carsten (1997) affirms, the house is more than a domestic unit. It is a place where people "become kin", one that simultaneously reproduces the community and the hearth.

It is thus possible to argue that "land" and "house" do not correspond to an opposition between public and private spheres, nor do they concern separate domains. Land is home. When women perform their tasks in and for the house, in and for the land, they are also creating bonds between their families and territory. The house, which is the place of intimacy and familiarity, is also where the relations with territory and community are materially and publicly expressed. Hence, where land conflicts are concerned, the more salient threats and more deadly attacks will be directed towards the house. Where land is at stake, all the bodies that live on it are targeted, which places women and children at the centre of the crossfire. Livestock can also get killed, destroying wealth and posing an explicit threat to the family, since animals are part of their owners, and the movement of livestock demarcates a family's land'.

In the context of land conflicts, homes are more than places where violence becomes inscribed. They are living entities. As Feldman claims (1991), the body is transformed and invested with agency through the embodiment of violence. The same happens with land. In Francisca's experiences, she and her family are publicly marked as "others" by the lumber company, and their land is claimed as "Zattar land" before the whole community. Land becomes a disputed entity, a place claimed by different owners.

\footnotetext{
5 Jorge Teixeira and I have written about the ethical ways that animals share in social life in rural landscapes (Teixeira \& Ayoub 2016). Throughout the last decade, a number of studies have discussed the mutuality of being between humans and animals in rural contexts in Brazil, as expressed in affection (Andriolli 2011), movement (Pereira 2015), or kinship (Leal 2014).
} 
Speaking of the murder of her husband and the attacks that she has suffered, Dona Francisca reveals that these experiences of violence also make her and her family as the legitimate owners of her land, which is, in turn, also produced in conjunction these events and the relations they put into motion.

To strengthen her claims, Francisca sought support in the Squatters Movement. The organization's attorney instructed her to claim property rights by entering a suit of acquisitive prescription, since she had lived there for more than ten years ${ }^{6}$. Francisca had stood her ground and faced up to the shooting, the threats (she could not leave her house since the "hit men" wanted to kill her), the jagunços taking her yerba mate and pinhão. "I suffered many times, because I knew they wanted to take me away from here. If they tried, I would place myself in front of the land's gate with the children and all my stuff. No way would I leave", she told me. After many years through the courts, Francisca won the suit. She attributes her victory to Our Lady of Aparecida, for she had promised the Virgin that if she won she would build a new house and undergo an "angel's table", which is a common ritual that Pinhão's inhabitants perform to pay promises made to the saints, the Holy Spirit and the Virgin. They prepare a "table", i.e., a meal, and feed the "angels", which are represented by children from the family and community. At the end of the ritual, a pole with the flag of Our Lady was placed in front of Francisca's new house. Planted in the ground, the pole was a symbol of both her devotion and the grace she received. Francisca thought the "debt" was finally paid. But Zattar is still legally claiming ownership over her lands.

\section{Paulão's death}

Even before meeting Dona Ana I already knew of her remarkable feat: she is the woman who killed a jagunço. This story is widely known and discussed, specially by the squatter women that regularly experience obstructions and abuses from the company's armed men. When they talk about 'Zattar's jagunços", Paulão is always remembered. They told me how "bad" he was - so bad that he ended up getting killed by a woman.

The first time I went to her house, Dona Ana narrated her role in conflicts with Zattar. "Things got ugly around here nineteen years ago", Ana said. "They started pressing our neighbours and a lot of people went away". She told me the story of Paulinho, who was working on his family's land when his godfather, Paulão, arrived with other jagunços. Dona Ana says that he screamed to Paulão: "For God's sake, godfather, don't kill me!" Paulão killed him with two shots.

Dona Ana also mentioned another occasion, when she was working at the barn and Paulão and his fellow armed men surprised her. "He pestered me a lot that day. He rubbed his gun in my face and said I was a dove to his weapon, while my husband was a jacu" (a big bird, which is hunted for its meat). Then the jagunços burned the barn. They always showed up in Dona Ana's family land to watch what she and her husband Seu José were doing, and to prevent the couple from carrying on with their work. "Paulão was kind of related to José, he was married to my husband's cousin", Dona Ana emphasized, and then added that the jagunço was also their "wedding godfather".

6 Acquisitive prescription is a legal method of achieving rights over land through continued possession. Legally, in Brazil, there are various forms of acquisitive prescription, distinguished by the size of the estate, the number of years of possession, and the form of occupation, among other factors. Residence on the land and productive activities are fundamental to suits of acquisitive prescription.

7 In Pinhão a person can have many godfathers and godmothers. These relations are established in a broad range of Catholic rituals, such as: birth baptism, which can occur not only at church, but also at home and at Saint João Maria water fountains; confirmation; marriage. The ritual in question has some important implications on the choice of the godparents, which is usually made by the children's parents when it comes to baptism, and influenced by them in the other rituals. In general, baptismal godparents are chosen among close kin. These are the most important godparents, since they assume the nurture of the child in case the parents die. The other godparents can be people with whom the goddaughter/godson and his or her parents are friends. This type of ritual kinship also recognises ties of reciprocity, and asking someone to be a godparent is taken as high praise, a sign of appreciation. In this cerimonies, godparents and the godchildren's parents become compadres ou comadres, also sealing a new ritual kinship relation. 
When the residents of the areas appropriated by Zattar tell their stories about land conflicts and the acts of the lumber company, they do not consider the armed men to be outsiders to the relations that constitute social life in Pinhão. At the same time, jagunços are depicted as strangers who are incapable of communication and reciprocity with the people who live in the lands claimed by Zattar. They are thus perceived through a perspective that resembles what Thiranagama and Kelly (2010) have written regarding "treason", which they interpret to be the "dark side of intimacy", an ethical issue which is the product of contradictory obligations that cause vulnerability and anxiety in relations between neighbours and relatives, infecting daily interactions with suspicion. Jagunços are ambiguous subjects who are loyal to a boss and, at the same time, friends or relatives of the people who are threatened by that boss.

Paulão was godfather to Paulinho and Ana, and he was married to a cousin of Seu José. Ideally, a godparent must protect and care for his or her godchild, since they share a covenant contracted in God's view, during a religious ceremony. While kinship may be made through acts (Carsten 1997; Lambek 2011), these acts are not enough to stabilise the relation, which can be imperilled by further acts. However, when Dona Ana remarks on Paulão's kinship relations with those he killed and threatened, she is expressing more than a bond that comes undone. She appraises how the acts of a person can turn that person into someone who is "odd", "bad" or "devastating". Paulão's excess is, therefore, expressed via his transformation from familiarity into strangeness when he kills his own godson and calls his goddaughter a "dove", i.e., a hunter's prey.

One day, Dona Ana and a little boy who she took care of were walking through her family land when she saw Paulão and his gang painting the fence. "Why are you painting this old fence? You should have come earlier, when it was new, not now that it is rotten!', Dona Ana said to them. She was mad, for jagunços painting the fence was also an offense, a statement that Ana's family land belonged to Zattar. Paulão got irritated with the woman's affront. He threatened to tie her up and make her watch them paint the fence. Dona Ana ran away with the boy. She said she was afraid that Paulão would harm the child as he had done to Paulinho. "I ran inside the house and took the rifle, which wasn't even working properly", Dona Ana said. Then she went outside again, and stood behind a tree, near the fence. From there she shot Paulão twice. He died instantly.

When I met Dona Ana she was awaiting her trial. When it was over, the judge ruled that she had acted in self-defence, and she was acquitted. The women who live in the lands seized by the company have always spoken of Ana with admiration, stressing that it took "guts" to kill that "disturbing" and "bad" man, that "slayer". Francisca's daughter, Julia, told me Dona Ana's story more than once. "God forgive me, but Ana did us a favour", she used to say after telling me about Paulão's death. He was one of the jagunços that pestered Francisca's family. When other women told me about Paulão, they treated his death as exemplary: "the one who is overbearing dies by the hand of the one who is weaker".

"Overbearing" is an adjective that defines the person that establishes a hierarchy between him or herself and the other, suppressing reactions or causing suffering, thereby turning the other into a "weaker" one. "Weakness" is characteristic of a person who is not expected to react to another with the same force, a trait that, like "overbearing", is connected to social relations. Mothers, for instance, might be "overbearing" to their children, and a child might be "overbearing" to another child that he or she judges "weaker". But in land conflicts, it is male armed figures working for a company that consolidates a territorial domain who are "overbearing". If jagunços considered most of the squatters "weaker", children and women were considered the weakest, for nobody would predict a strong reaction from them.

In the stories about the company's armed men, the "overbearing" jagunços are also those who "abuse" people the most. "To abuse" also means to push one's luck, i.e., to underestimate the danger that one's acts might bring upon one. Those who are "overbearing" thus risk getting frustrated: blindly trusting in their 
force, they are prone to be misled by those who are "weaker". This is why I would not agree with a reading of these events that interprets Dona Ana as the transgressor of a code that relegates women to passivity and men to action when it comes to violence. If she did the unexpected (the weakest in this case upends the abuser), it is through a performance that is invested with moral values concerning family, femininity and violence. Moreover, the unexpected is precisely what is expected in stories of violence - so much so that forms a proverb: "the one who is overbearing dies by the hand of the one who is weaker". Dona Ana's story serves to remind the jagunços that there is, after all, no "weaker" party. The question we must ask, then, is not if Dona Ana is an exception, but how a woman can kill a man and become an example.

Jagunços are renowned as "brave" men who had always fought among themselves, and who had killed other men before becoming employees of Zattar. In Pinhão people tell many stories about the men of the "old times", who walked everywhere carrying guns on their belts. Any disagreement could result in shots being fired. The gun was part of the male subject, a component of masculinity. And that is why Dona Ana's act is unexpected: guns are not, ideally, the stuff of women. Yet there are stories of women who killed husbands who were violent to them, cheated on them, or because of land issues. I also heard stories of women from the "old times" who took part in their "family struggles". These women used to carry their guns in the company of their male relatives, and they also knew how to take the life of a person who had killed their kinspeople. Furthermore, women know how to handle guns and rifles. Their fathers, brothers and husbands usually teach them how to use firearms. While women are not expected to walk around carrying a gun, they learn how to use it in self-defence. Guns are hence also a means through which women morally cultivate themselves; but this aspect of women's identity is not emphasized when people describe women in the Pinhão countryside. The distinctive elements that confer on them authority are: marriage, motherhood, "service", and their families' reputations.

When stressing their relationship to their land, Francisca and Ana emphasise their role as mothers and wives. Vianna and Farias (2011) have shown how motherhood provides moral authority to women whose sons were victimized by the police in Rio de Janeiro. The political activity of these women are centred in questioning the disruption of their homes, which are constantly invaded by the police and devastated by the loss of their children. Women in Pinhão are also speaking of a violence that invades their homes and throws their lives into the centre of the conflict. It is also motherhood that empowers them in those cases, for nurturing and taking proper care of their children is seen to be their main duty. But women in Pinhão are not part of a specific social movement, such as the mother's movements that Vianna and Farias study. Their experiences are part of the political demands of social movements, but they do not usually fulfil leadership roles in these organizations.

As Mahmood stresses, "agentival capacity is entailed not only in those acts that resist norms but also in the multiple ways in which one inhabits norms" (Mahmood 2005: 15). The agency of women can be expressed in forms of action and in the construction of moral subjects within the "norm", and not only through its transgression. This is a focal point of the stories of women who kill men in Pinhão, and in the stories about the jagunços of Zattar. These women are not opposing the gender morality of their social world. Instead, they are making use of their own position as wives, mothers, daughters and members of families to confront men and Zattar. If the "fights" of "brave" men are directed towards other, equally "brave" and armed men, land conflicts encompass the house and the family who dwells in it. This, coupled with Paulão's behaviour, gave Dona Ana the guts to kill him. It does not make her a "manlier" woman. Her story is the story of a woman who sees herself threatened as a mother and a home owner. It is in this sense that other women identify themselves with Dona Ana, and remark that Paulão got what he deserved. It was their world he destroyed. 


\section{The time of vengeance}

While squatter women speak of Paulão's death as a relief, his daughters want to kill Dona Ana. It was Francisca, who is Dona Ana's comadre and lives in a “community” close to Paulão's daughters, that told me about their plans for "vengeance". These women all attend the same church; they know each other's families and also the other families who inhabit that region of Pinhão. Although they are not "neighbours" and do not live in the same "communities", Dona Francisca, Dona Ana and Paulão's daughters constitute and are constituted by the vicinage relations that compose places in Pinhão's countryside.

Pina Cabral and Godoi (2014) propose the notion of "vicinage" to define the plural logics (kinship, friendship, affinity, etc.) through which places of habitation are territorially bonded and bounded. In Pinhão, the "communities" are indexed by the presence of a Catholic or Protestant church, which occupies the centre of these localities. Around the church we find a school, a small public health centre, bars and houses. Most of the communities' dwellers live in lands that are not immediately next to the church. I call them family lands, since they are inhabited by different family members. After marriage, some of the sons and daughters usually build their own houses in specific plots of the family land, over which they acquire rights.

Every "community" member knows the others. They can have ties with "people" from other "communities", particularly adjacent ones. For instance, Dona Francisca has a brother who lives near the former gated settlement of Zattarlândia and whose son is married to one of Dona Ana's daughters. One of Ana's daughters married a young man from a family that lives in Francisca's "community". Marriage is a bond that binds families from different "communities", but there are other movements that connect them. They can attend the same churches and the same parties at the houses of acquaintances. They can work at the same places, mutually assist each other, visit each other, or catch the same buses in their trips to the municipality's urban area. Moving between houses and other places, people also engage in conversations and ratify relations; relations that can likewise provide lines of fracture in future conflicts (Comerford, Carneiro \& Dainese 2015).

When Dona Francisca hosted the "angels table" at her house, she was worried about inviting Dona Ana and Paulão's daughters. She knew that the latter wanted to kill Dona Ana and had threatened her publicly. Francisca told me that one of these threats occurred inside the church. Paulão's daughter sat on the pew beside Ana. She turned to the woman who killed her father and whispered: "your number will soon come up". Dona Francisca then repeated Ana's reply to the woman: "Only God knows when my number will come up. Maybe yours will come up before mine". On another occasion, the other daughter raised a fuss when she encountered Dona Ana in the bus that takes people to the urban centre. She shouted to everyone that Ana would still pay for her deed.

"Vengeance" is a common theme in stories about deaths by homicide in Pinhão, since people see retribution as the means to "resolve" an unsettled grievance. From the moment it bursts into the world, "vengeance" is grafted onto the ethics of ordinary life. When Foucault (1984) connected the notion of ethics to the production of moral subjects, he stressed the stylization of conduct and caring for oneself and others as practices that do not simply reflect rules and obligations. Such practices and habits are cultivated through people's actions and relations to one another, therefore expressing how subjects are engaged with morality. Recently, Michael Lambek (2015) and Veena Das (2012) have discussed that ethics is immanent to human life; it is part of how life is lived with others. Therefore, while Das sees ethics in "the small disciplines" that people perform in their everyday (Das 2012: 139), Lambek understands the "ethical condition" as intrinsic to human action, for it concerns the different ways people relate to criteria and exercise practical judgment (Lambek 2015: 38). 
Typically, killings are "resolved" by the dead person's closest relatives: his parents, brothers and sisters, sons and daughters. They are the ones who "swear vengeance on the coffin" that carries the dead person. Both the family of the person who is killed and of the killer also embody that death, which becomes another element in the "mutuality of being" (Sahlins 2011: 2-3) that constitutes kinship ties. The members of the families of the deceased and of the killer will avoid encounters and keep a distance if they meet; other persons who know them will also make efforts to prevent encounters between them.

Campbell (1964), Bourdieu (1972) and Herzfeld (1985) have explored, in different ways, the implications of homicide in relationships between families. All include aggressiveness and violence as masculine traits, connected to values of "honour". Women appear as honourable subjects, albeit their honour is attached to sexual decency and domestic relations. When homicides therefore affect families, it is men who are called upon to act publicly. In Pinhão, "vengeance" is usually enacted by and on men, and weapons are considered a trait of their masculinity. Yet, when it comes to land, women can become victims of violence and embrace guns as instruments for their own protection. For instance, Dona Ana killed Paulão inside her land. His daughters, then, took on the mantle of "vengeance", which is here an issue between women. In contrast to the "vengeance" stories involving men, Paulão's daughters confront Dona Ana publicly with words and gestures. They approach and defy, while men usually confront to kill. Killings and vengeance are thus also a matter of and for women, but men and women perform vengeance differently.

"Vengeance" is not a rule that everyone must compulsorily follow, and to seek is not necessarily to execute it. As Marques (2002) points out concerning issues (questões) and intrigue (intrigas), in Pernambuco, a killing unveils and qualifies a new state of relations. Although retaliations might occur, they can also remain latent and feed the tension between the parties. In Pinhão "vengeance" irrupts as an "oath" that signals a rupture between the families involved in a murder, reverberating thus across the broader community and friendship relations. The people that coexist with those families take an interest in the "oath" and its possible outcome. In Ana's case, "vengeance" becomes a preoccupation for Francisca, who now has to assess how to talk about it and how to handle encounters with the implicated parties. The only certainty surrounding "vengeance" is that it can happen. Nobody knows exactly when it will occur, or even if it is in fact going to occur. While "vengeance" remains in the horizon, it expresses an open wound, a possibility that can be the starting point for numerous narratives (Gilsenan 1996).

Francisca and Ana live through dilemmas concerning the possibility of retaliation. When the former hosted the "angel's table" at her house, she had to manage her relations with Ana and with Paulão's daughters. Not inviting one of the parties would put Francisca in trouble, for she would create "grievance" between herself and the absent person. In Pinhão's countryside, people give great importance to visits, greetings and party invitations. The interruptions of these invitations is taken as an offense, a grave disregard for someone. And specially in this case, not inviting one of the parties could be seen as an act of support for the other. Francisca decided to invite them all, and assumed the risk of a scandal in her own house. Fortunately, the women stood far from each other during the celebration.

Ana's dilemma is different. She killed Paulão due to a land conflict in which he acted as a jagunço. He was a familiar person, not an employee that went to work and left at the end of the day. Paulão lived with his family in a land near Dona Ana's community, and his death became his daughters' problem to "resolve". Killing the jagunço may have given Ana and many people some peace, but this did not last long. She is now wanted dead. Moreover, her problems of land ownership have not come to an end, since Zattar still maintains its land titles in Pinhão.

The fact that the activities of Zattar Industries can lead a woman to kill a jagunço, and to become a person wanted dead in "vengeance", is evidence that we cannot separate violence in land conflicts from the social relations and ethics of communities and families in Pinhão's countryside. Medeiros (1996) highlights 
the political aspects of violence against rural workers, and claims that violence is a "traditional pattern of domination", also inscribed in the possibilities of social relations. Jagunços are historically attached to forms of land expropriation and territorial domain in Brazil, and they are also part of Pinhão's rural communities. Their work cannot be separated from the vicinage bonds and forms of moral conduct that are valued in the countryside of the municipality. That is also how the company's actions are significantly attached to the daily lives and sociality of Pinhão. To understand experiences of violence in land conflicts, we must observe how large landowners and their armed agents participate in the life that is lived in the lands in which they act.

The central role of vengeance in "honour crimes" accounts for the occupational vocation of "hit men", as presented in Barreira's works (Barreira 1992, 1998). The author reiterates that, historically, large landowners have used violence as a display of force. This allows us to consider that men who are paid to murder rural workers can rely on the logic of "vengeance" to make their actions seem to be retaliations, and therefore legitimate and reasonable reactions to former blood shed in their own families. Villela (2004) further discusses the relations between vengeance and politics, confirming the centrality of retaliatory acts in the constitution of political alliances. In his ethnography, kinship provides the idiom by means of which political groups and vengeance cycles are conceived. Kinship, politics and violence therefore emerge as connected, rather than distinct, domains. Finally, in Barros' account of conflicts in Japuara, in the state of Ceará, vengeance occurs during a police siege against rural workers. A man that accompanied the police killed a rural worker and then claimed it as an act of revenge, since his brother was killed during the siege (Barros 2013: 96). Here, where vengeance takes place during a police raid, it emerges as an aspect of State violence.

Vengeance cannot therefore be taken as a form of customary violence, a code pertaining to old structures of social regulation, or to private acts in the flow of major political conflicts. In Pinhão, "vengeance" is an actual form of dealing with homicides and a means for tying killings to social relations. While the actions of jagunços are seen as abuses, they are also managed within family and community, and therefore can be transmuted into other forms of conflict and hostility, as is the case with "vengeance". Comerford (2003) claims that conflict is an agonistic form of sociability, a dynamic process that underlies the course of familiarity and living together, and which refers to an economy of respect and tension. In places such as those where Francisca and Ana live, land conflicts are also agonistic relations and conducts, hence affecting intimate bonds between people. It is through these tense ways of living together that deaths and hostilities endure and can always engender new violent actions. But this does not mean that conflict and violence are kept within accepted boundaries, nor that they fail to cause destruction in their wake. Horror, excess and fear also become a major part of people's lives and relationships.

\section{Of children and slaughter: horror and community}

The last few times I went to Dona Francisca's land, she and her family told me about recent events that had appalled them. One of these events occurred in 2014, when arson resulted in the deaths of three children. The boys that died were brothers aged eight, ten and twelve. They lived with their mother in a Landless Rural Workers Movement (MST) camp, which is close to Francisca's land, situated in one of the areas that Zattar Industries "offered" to the Incra (National Institute of Colonization and Agrarian Reform) in 2006. The landless workers occupied these areas in 2007, and Francisca's land was the first base camp of their organization, where they initially settled before occupying the company's areas. During the first years of the camp, the landless workers lived in "shacks". In time, they built wooden houses in the lands, which are now divided into "lots" that belong to specific families. 
Standing next to the wood-burning stove, Francisca and her daughter Fátima talked about their exasperations and doubts concerning the children's death. The boys were alone in the house, because their mother, who was divorced from their father, had gone to the city. The fire was set at night and spread quickly. The youngest of the boys managed to make his way out of the house, but he was severely burned and died at the hospital. His two brothers died inside their home.

According to Francisca, people were commenting that the boys had themselves caused the fire. The police claimed it was an accident. Maybe it could have started from the wood-burning stove's ashes, or perhaps a candle fell and the fire spread. "But look, if they had started the fire, they would have left the house, they would have jumped out the window, I don't know! And at least the older one, who was already twelve, would have had a chance to save himself or to help the younger ones!', Fátima said. Francisca then stressed that the house was made of freshly cut wood. "It's really hard to burn that kind of wood. If they couldn't manage to escape, it is because the fire spread really fast. And the fire could only have spread fast if another substance had fuelled it". Francisca and Fátima concluded that someone had spread gasoline around the house and then lit it. "Who could have done such thing?", I asked them. "Look, Dibe, we cannot say who it was for no one saw", Dona Francisca replied. "But we have our suspicions", she concluded.

The suspicions were based on events that had been occurring since the landless workers settled in the area. Claiming the ownership of the lands, a family named Junqueira attacked the members of the social movement, setting fires and arranging drive-by shootings. They filed a suit of ownership repossession against the MST, but it was unsuccessful since the land titles belong to Zattar, and the lands are being negotiated with the Brazilian State through Incra. However, legal setbacks failed to stop the Junqueiras from forcibly claiming the lands. No further police investigations were undertaken to identify what may have caused the fire that killed the three children.

Francisca and Fátima's words were laden with sadness. Fátima, who works at the school where the boys studied, said she used to see them everyday and that, now and again, when she is working, she remembers their faces. After she made that statement, Gabriel, her nine-year-old son who was listening to our conversation from the living room, came in to the kitchen, pulled up a chair, and joined us. "Going to school was a really sad thing after they died. One of them was our age and used to play with me and Rafael (Gabriel's cousin). We were always together", Gabriel said in a low and serious tone, with his legs drawn up. Silence overtook our conversation. We changed the subject.

When the dwellers of Pinhão talk about killings that occur between men and women whose interactions is pervaded by hostility, they usually call these events "fights", "troubles", "vengeances", and "settling of scores". All of these expressions refer to possibilities of assassination that emerge in the dynamic of agonistic relations. Even if they are considered "ugly things" and engender pain, they are also taken as events that "might happen", i.e., as understandable outcomes to hostile situations. Children stand as expressive limits to how far killings can go, for their assassination is "what cannot happen". When a child is murdered or witnesses a death, we are in the domain of "evilness", "absurdity" and "violence". Children are not only "weaker" persons who must be protected and nurtured, they are also "angels" in the eyes of God, as the religious ritual that Francisca performed observes. Their assassination is therefore considered a grave transgression, and the person who does it stands outside the conceivable world.

In her discussion about child killings in land conflicts in Amazonia, Andrade notes that these crimes are not based on an "honour code", or in "divergences between families" (Andrade 1993: 48). The author argues that the main objective of these crimes is to "disrupt peasant families". Hence land conflicts are characterized by violent acts that exceed agonistic sociality, for the objective is to destroy the family's relation to a piece of land. If people move away to flee from "vengeance", in this case they cannot just go away, for their purpose is to have a piece of land. Therefore, mass killings, arson and hired murderers 
are central to land conflicts, because the intention of those who organize such acts is to destroy people's attachment to the territory. The death of children, then, is more than an event that dismantle a family. It strikes at the fabric of the social world, spreading terror. Veena Das observes that "boundaries between the ordinary and the eventful are drawn in terms of the failure of the grammar of the ordinary", when our knowledge of how the world is supposed to be is "put into question" by violence that does not find ways of being said in the forms of everyday life (Das 2007: 8). The assassination of children and the fires are thus not predicted in that grammar of the agonistic sociality that includes "vengeance". Although these horrific acts are mentioned in people's narratives, they are not commented as crimes that entail retaliation, for any possibility of response fails in light of such brutality.

Moreover, even "vengeance" has its limits. The Junqueiras are also the central characters in retaliations that resulted in a massacre. So many people were killed that the story became widely known and discussed in Pinhão. The family want more than the lands occupied by the landless workers. They are also claiming the lands of other small landowners in their community, such as the Ventura family. In June of 2016, the dead body of Marcio Ventura was found by the roadside. Months later, it was Roque Junqueira who was found dead in the bush. In November 2016, Bruno Ventura, an eighteen-year-old boy, was shot as he was arriving at the gate of his family's land. He was taken to the hospital and survived. Four days later, his sister Jocelia was shot to death at the edge of a water fountain. After that, the Venturas left their land. In September 2017, they returned. A week later, when Felipe Ventura was with his fellow workers in a truck, the Junqueiras ambushed them. Felipe and two of the other workers were killed. Before dying, Felipe managed to shoot and kill Leozil Junqueira.

"Can you believe that, when all of this happened, a policeman said on the radio that there had been no assassinations in Pinhão since 2014?", Dona Francisca asked me after narrating the ambush, which was witnessed by children who were on their way to school. "What kind of police is that?", Francisca continued. Then Fátima said that the police went to the Junqueira's lands, had coffee with the family, and did not arrest a single one. "No one gets arrested, nothing happens", Dona Francisca said. The remaining Venturas left once again. On the edge of the road where the killings took place, there is now a big cross, right in front of the fence of the Junqueiras' land.

Although some of my friends that live in other rural communities said that this massacre was the result of "family vengeances", they also questioned this way of classifying these acts. If "vengeance" leads to the possibility of retaliation, and therefore to a story that can go on for a long time, killing a whole family or extending retaliation cycles to their limit is an absurd possibility, for it leads to annihilation. It is also not common that four people, two of which were not even members of the families involved in the "fight", get killed at the same time. When Francisca talked to me about these events, she always stressed Jocelia's murder, the appearance of her dead body, her baby who was still breastfeeding. She also kept going over the scene of the children passing by four dead bodies covered in blood. "How could they kill a woman, a baby's mother?"; "What kind of person ambushes a truck at seven in the morning in the middle of a road used by everyone?"; "Two of the dead had nothing to do with the story, they lost their lives for nothing". These were some of Francisca's queries, which show that the Junqueiras had transcended the terrain of vengeance. What they carried out was a "slaughter", as Francisca and Fatima called it, which was understood as an absurdity that was related to other acts that they had previously performed. The Junqueiras had shown everyone that they are willing to do anything in order to take other people's lands.

Though horror fails the grammar of agonistic relations, it also retroactively enters it after violent events. The Junqueiras, for instance, live close to Francisca's family. They are within the community, just as the jagunços were. Their actions, movements, lands, work activities, and relations to other people are observed and traced in conversations, therefore entering the activities of "watching and telling" which 
are so important in "agonistic sociability" (Comerford 2014). They might be taken for "crazy people" or "bandits", but they are still part of the community's life. The absurd, thus, steps into the everyday as fear shared by everyone who passes through the road where the ambush occurred. That fear attaches to relations, lands, places, movements. To live in lands that are desired and attacked by others, as Francisca says, is to live a life where "only God can protect us".

\section{Concluding Remarks}

This work discussed how women in Pinhão, Paraná conceptualize violence in land conflicts. Their stories bring to the fore two main themes: 1) land and violence are also constituted as women's problems, and thereby as matters that encompass gender; 2) violence in land conflicts is conceptualized through ethical forms that embrace family and community relations. It is therefore a subject apprehended from within sociality.

Women show us that, when it comes to land conflicts, land is a living entity that is inseparable from house and home. Although some studies have demonstrated that land is a masculine subject, women stress that land is the place where a family lives. The house stands as the materialization of land ownership and it is therefore the main target for an enemy. It is their duties and acts as mothers, wives and land workers that are foregrounded when women talk about the ways that they act in conflicts and violent situations.

Ethics is also a central theme. When women talk about violence, they also assess how someone acts in terms of care for oneself and for others in family and community. If some of the company's armed men are taken as "good" people - as Francisca's husband, who is considered a mere "guard" - they might also be judged as persons who, in the course of their conduct, become detached from the community. This is the case of Paulão, the jagunço killed by Dona Ana, who, for her part, is now wanted dead by the man's daughters. Since "vengeance" is a common way to handle killings in Pinhão's rural communities, it is also part of the agonistic relations that constitute rural communities and of the grammar of fighting and killing that is practiced in these communities. But there are acts of violence that fail that grammar, such as those perpetrated by Paulão himself. When children are assassinated, houses are burnt down and "vengeances" extend to massacres, the ordinary possibilities of conflict and violence are trespassed. Horror, then, enters sociality as fear and incomprehension. It is also through vicinage relations that violence endures in these women's lives. Hence, even if the land issue is resolved, the violent acts that have happened throughout these struggles are already part of people's coexistence.

Land remains a disputed matter for families who inhabit the areas that Zattar acquired in Pinhão. Now the members of social movements face other enemies, such as the Junqueiras, who claim the lands inhabited by the MST and other dwellers. But we cannot forget the lumber industry, which still owns the lands titles. While Zattar is negotiating lands with the State, it has also gained legal claims of ownership repossession against squatter communities. In December 2017 the whole community of Alecrim was evicted. The police expelled the squatters from their homes and then destroyed their houses, fences, barns, the community's church, and the free clinic. The eviction generated despair throughout the municipality. The social movements blocked the most important highway in the region and demanded actions from the State. The National Institute of Colonization and Agrarian Reform (INCRA) reaffirmed its commitment to solve the land problems in Pinhão, and the Paraná State Public Prosecution's Office managed to halt other planned evictions until December of 2018.

In a meeting that occurred in February of 2018 in one of the squatter communities threatened with eviction, one of the men who leads the Squatters Movement proclaimed the following: "The enemy is still alive, and he no longer acts with jagunços. He uses much worse means". This remarkable statement 
also shows how violence endures in the everyday, and how its forms are multiple when it comes to land conflicts. Zattar persists, and so does the struggle of the members of social movements. The company might not use jagunços anymore. But the destruction of people's homes is still its objective. The "worse ways" are, of course, legally instituted evictions, which can put hundreds of families in disgrace.

Violence in land conflicts consists of actions that threaten the continuity of people's relations to the places where they live and work. To continue to live in disputed land is hence to face the possibility of the destruction of the family, as well as of the social world as it is known and experienced. It is no wonder that people emphasize that if Zattar accomplishes the planned evictions, Pinhão will fall into chaos. Yet when we pay attention to how women express the possible destructions, it becomes clear that there are diverse relations of familiarity at stake. This is not only because Junqueiras and jagunços live nearby, but also because land is the place where social intimacy is produced. It is this domain of intimacy that women refer to in their stories: forms of relating and living that are interwoven with power relations, politics of land ownership and potential killings and destruction. Yet, as we can see, chaos and destruction do not detain these women. They are also fighting for life.

Received: December 30, 2017

Approved: January 10, 2018

Revision: Luiz Costa

\section{References}

ALMEIDA, Alfredo Wagner Berno de. 2006. Terras de Quilombo, Terras Indígenas, "Babaçuais Livres",

"Castanhais do Povo", Faxinais e Fundos de Pasto": Terras Tradicionalmente Ocupadas. Manaus: PPGSCA-

UFAM.

ANDRADE, Maristela. 1993. "Violências contra crianças camponesas na Amazônia. In: José de Souza Martins (org.), O massacre dos inocentes: a criança sem infância no Brasil. São Paulo: Editora Hucitec. pp. 37-50. ANDRIOLLI, Carmen Silvia. 2011. Sob as vestes de Sertão Veredas, os Gerais: "Mexer com criação" no Sertão do IBAMA. Tese de Doutorado, Universidade Estadual de Campinas - Campinas.

AYOUB, Dibe. 2013. "Os posseiros do Pinhão - conflitos e resistências frente à indústria madeireira”. In:

Liliana Porto, Jefferson de Oliveira Salles, Sônia M. dos Santos Marques (orgs.), Memórias dos Povos do Campo no Paraná - Centro-Sul. Curitiba: ITCG. pp.151-172.

. 2015. "Guardas, jagunços e pistoleiros: narrativas sobre homens de armas em um conflito de terras". Ruris, 9(2): 13-44.

BARREIRA, César. 1992. Trilhas e atalhos do poder: conflitos sociais no sertão. Rio de Janeiro: Rio Fundo Editora. . 1998. Crimes por encomenda: violência e pistolagem no cenário brasileiro. Rio de Janeiro: Relume-Dumará, Núcleo de Antropologia da Política.

BARROS, Francisco Blaudes Sousa. 2013. Japuara, um relato das entranhas do conflito. Brasília: Ministério do

Desenvolvimento Agrário.

BOURDIEU, Pierre. 1972. Esquisse d'un théorie de la pratique. Genève: Editions Droz.

BRUMER, Anita; TAVARES DOS SANTOS, José Vicente. 2006. "Estudos agrários no Brasil: modernização, violência e lutas sociais (desenvolvimento e limites da Sociologia Rural no final do século XX)”. Revista Nera, 9: 49-72. 
CAMPBELL, John K. 1964. Honour, Family and Patronage. Oxford: Clarendon Press.

CARSTEN, Janet. 1997. The Heat of the Hearth: The Process of Kinship in a Malay Fishing Community. Oxford: Oxford University Press.

; HUGH-JONES, Stephen. 1995. "Introduction: About the house - Lévi-Strauss and beyond". In: Janet Carsten; Stephen Hugh-Jones (eds.), About the house: Lévi- Strauss and beyond. Cambridge: Cambridge University Press. pp. 1-46.

CERQUEIRA, Ana Carneiro. 2017. “'Mulher é trem ruim': a 'cozinha' e o 'sistema' em um povoado nortemineiro". Estudos Feministas, 25(2): 707-731.

CHANG, Man Yu. 1988. Sistema Faxinal: Uma forma de organização camponesa em desagregação no Centro-sul do Paraná. Londrina: IAPAR.

COMERFORD, John. 2003. Como uma Familia: Sociabilidade, Territórios de Parentesco e Sindicalismo Rural. Rio de Janeiro: Relume-Dumará. . 2014. "Vigiar e narrar: sobre formas de observação, narração e julgamento de movimentações". Revista de Antropologia, 57(2): 107-142.

; CARNEIRO, Ana; DAINESE, Graziele. 2015. "Giros etnográficos em Minas Gerais: Casa, comida, prosa, festa, política, briga e o diabo". In: J. Comerford, A. Carneiro, G. Dainese (orgs.), Giros etnográficos em Minas Gerais: casa, comida, prosa, festa, política, briga e o diabo. Rio de Janeiro: 7 Letras: FAPERJ. pp. 9-27.

DAS, Veena. 2007. Life and words: violence and the descent into the ordinary. Berkeley: University of California Press.

. 2012. "Ordinary Ethics". In: D. Fassin (org.), A Companion to Moral Anthropology. Chichester: WileyBlackwell. pp.133-149.

FELDMAN, Allen. 1991. Formations of Violence: The Narrative of the Body and Political Terror in Northern Ireland. Chicago and London: The University of Chicago Press.

FOUCAULT, Michel. 1984. Histoire de la sexualité, t. II - L’usage des plaisirs. Paris: Gallimard.

GILSENAN, Michael. 1996. Lords of the Lebanese Marches: Violence and Narrative in an Arab Society. London-New York: I. B. Tauris Publishers.

GUEDES, André Dumans. 2013. O trecho, as mães e os papéis: etnografia de movimentos e durações no norte de Goiás. São Paulo: Garamond.

HEREDIA, Beatriz Maria Alásia de. 1979. A Morada da Vida: trabalho familiar de pequenos produtores do Nordeste do Brasil. Rio de Janeiro: Paz e Terra.

HERZFELD, Michael. 1985. The Poetics of Manhood: Contest and Identity in a Cretan Mountain Village. Princeton: Princeton University Press.

LAMBEK, Michael. 2011. "Kinship as gift and theft: Acts of succession in Mayotte and Israel". American Ethnologist, 38(1): 2-16.

. 2015. "The ethical condition". In: Michael Lambek (ed.) The ethical condition: essays on action, person and value. Chicago: The University of Chicago Press. pp. 1-39.

LEAL, Natacha Simei. 2014. Nome aos bois: Zebus e zebuzeiros em uma pecuária brasileira de elite. Tese de Doutorado, Universidade de São Paulo - São Paulo.

MAHMOOD, Saba. 2005. Politics of piety: the Islamic revival and the feminist subject. New Jersey: Princeton University Press.

MARCELIN, Louis Herns. 1999. "A linguagem da casa entre os negros no Recôncavo Baiano". Mana. Estudos de Antropologia Social, 5(2): 31-60.

MARQUES, Ana Cláudia. 2002. Intrigas e questões: vingança de familia e tramas sociais no sertão de Pernambuco. Rio de Janeiro: Relume-Dumará.

MARTINS, José de Souza. 1981. Os camponeses e a política no Brasil. Petrópolis: Vozes. 
MEDEIROS, Leonilde Servolo de. 1996. "Dimensões políticas da violência no campo”. Tempo, 1: 126-141. PEREIRA, Luzimar Paulo. 2015. "O movimento dos bichos: notas etnográficas sobre animais, seres humanos e espaços em Urucuia, MG”. Ruris, 9(1): 63-84.

PERUTTI, Daniela. 2015. Tecer amizade, habitar o deserto: Uma etnografia do quilombo Familia Magalhães (GO). Tese de Doutorado, Universidade de São Paulo - São Paulo.

PINA-CABRAL, João de; GODOI, Emília Pietrafesa. 2014. “Apresentação: Vicinalidades e Casas Partíveis". Revista de Antropologia, 57(2): 11-21.

PORTO, Liliana. 2013. "Uma reflexão sobre os faxinais: meio-ambiente, sistema produtivo, identidades políticas, formas tradicionais de ser e de viver”. In: Liliana Porto, Jefferson de Oliveira Salles, Sônia M. dos Santos Marques (orgs.), Memórias dos Povos do Campo no Paraná - Centro-Sul. Curitiba: ITCG. pp. 59-77.

SAHLINS, Marshall. 2011. "What kinship is (part one)". Journal of the Royal Anthropological Institute, 17: 2-19. SOUZA, Roberto Martins de. 2010. "Na luta pela terra, nascemos faxinalenses": uma reinterpretação do campo intelectual de debates sobre os faxinais. Tese de Doutorado, Universidade Federal do Paraná - Curitiba.

TEIXEIRA, Jorge Luan; AYOUB, Dibe. 2016. "Cachorros que atacam criação: reflexões éticas sobre a mobilidade e a vida social dos animais em ambientes rurais". Iluminuras, 17(2): 136-165.

THIRANAGAMA, Sharika; KELLY, Tobias. 2010. "Introduction: Specters of Treason". In: S. Thiranagama, T. Kelly (eds.), Traitors: Suspicion, intimacy and the Ethics of State-Building. Pennsylvania: University of Pennsylvania Press. pp. 1-23.

VELHO, Otávio. 1976. Capitalismo autoritário e campesinato. São Paulo: DIFEL.

VIANNA, Adriana; FARIAS, Juliana. 2011. "A guerra das mães: dor e política em situações de violência institucional". Cadernos Pagu, 37: 79-116.

VILLELA, Jorge Mattar. 2004. O povo em armas: violência e política no sertão de Pernambuco. Rio de Janeiro: Relume Dumará.

WOORTMANN, Klaas. 199o. “'Com parente não se neguceia': O Campesinato Como Ordem Moral”. Anuário Antropológico, 87: 11-73. Brasília: Editora da Universidade de Brasília. ; WOORTMANN, Ellen. 1997. O trabalho da terra: a lógica e a simbólica da lavoura camponesa. Brasília: Editora da Universidade de Brasília.

Dibe Ayoub

Federal University of Rio de Janeiro, National Museum

Graduate Programme in Social Anthropology

https://orcid.org/oooo-0003-3516-8682

E-mail: dibeayoub@gmail.com 